\title{
粘士鉱物表面と機能性色素との相互作用の解明
}

\section{Interactions between the Surface of Clay Minerals and Functional Dyes}

\author{
藤村 卓也 \\ 首都大学東京 大学院都市環境科学研 \\ 究科 分子応用化学域, 日本学術振興 \\ 機構 DC1 \\ T 192-0397 \\ 東京都八王子市南大沢 1-1 \\ Takuya FUJIMURA \\ Department of Applied Chemistry, \\ Graduate Course of Urban \\ Environmental Sciences, Tokyo \\ Metropolitan University
}

Minami-ohsawa 1-1, Hachiohji, Tokyo

192-0397, Japan

高木 慎介

首都大学東京 大学院都市環境科学研 究科 分子応用化学域

干 192-0397

東京都八王子市南大沢 1-1

Shinsuke TAKAGI

Department of Applied Chemistry,

Graduate Course of Urban

Environmental Sciences, Tokyo

Metropolitan University

Minami-ohsawa 1-1, Hachiohji, Tokyo

192-0397, Japan
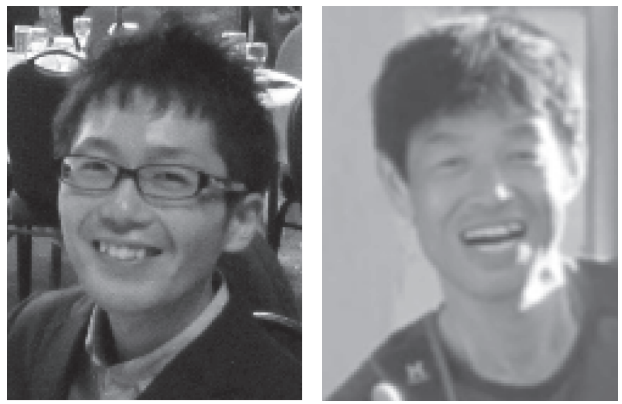

\author{
嶋田 哲也 \\ 首都大学東京 大学院都市環境科学研 \\ 究科 分子応用化学域 \\ 干 192-0397 \\ 東京都八王子市南大沢 1-1 \\ Tetsuya SHIMADA \\ Department of Applied Chemistry, \\ Graduate Course of Urban \\ Environmental Sciences, Tokyo \\ Metropolitan University \\ Minami-ohsawa 1-1, Hachiohji, Tokyo \\ 192-0397, Japan
}

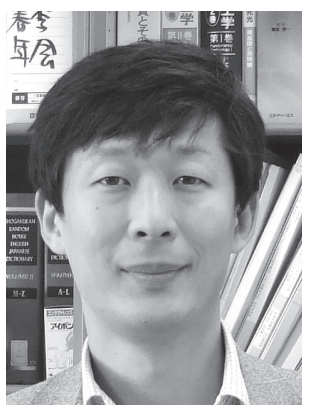

論文要旨：粘土鉱物は, 極めて多様な用途を有する汎用されている工業材料である。一方, 学術的にも, 原子レベルで平滑な界面を有する, 密度可変な電荷分布を有するなど, 極めて興味深い特徵を有している。 界面における，無機物と有機物の相互作用は普遍的に重要な研究課題と思われるが, 粘土鉱物一機能性色素 複合体はその好適な研究モデルであると考えられる。近年, 我々は, 静電相互作用と疎水性相互作用を利用 することで, 界面での機能性色素の吸着密度や吸着配向を操作しうることを見い出した。本稿では, 粘土鉱 物一ポルフィリン色素複合体に注目し，ポルフィリン色素の吸着状態についての概説を試みる。

\begin{abstract}
Clay minerals are commonly used industrial materials. On the other hand, they are unique and attractive materials form the viewpoint of science, because they have very flat surface and densityvariable anionic charges. Clay minerals-functional organic dye complexes are suitable model for the investigations on the interaction between inorganic surface and organic guest molecules, which are important subject in the field of surface sciences. Recently, we found out that the adsorption density and molecular orientation of porphyrin dye on the clay surface can be controlled. In this paper, the detailed adsorption behavior of porphyrin dyes on the clay surface is described.
\end{abstract}

Key words: clay minerals, porphyrin, electrostatic interaction, hydrophobic interaction, artificial light harvesting

\section{1 はじめに}

我々は, 人工光合成系の構築, 光機能性材料の開発を

連絡者：高木 慎介

E-mail : takagi-shinsuke@tmu.ac.jp
目指して，無機有機複合体について研究を進めている。 特に，無機物として粘土鉱物，有機物としてポルフィリ ン化合物をはじめとする機能性色素に注目し, その構造, 光機能について明らかとしてきた。植物の光合成におい ては, 主に蛋白質がホスト材料となり，各機能性分子の 
位置制御，化学的性質の制御を行っている。我々は，制 御が困難である蛋白質のかわりに特異な二次元平面，ま たは，三次元空間を提供する層状化合物の一種である粘 土鉱物を用いた複合系について研究を行ってきた。これ までの研究により, 粘土鉱物をホスト材料に用いること で，ポルフィリン色素の吸着集合構造の制御，または, 吸着配向制御が可能であることがわかってきた ${ }^{1,2)}{ }^{2)}$ 。そ のような構造制御, 光化学的な性質の制御を考えるとき, 粘土鉱物と，ゲストであるポルフィリン色素間の相互作 用は決定的に重要な役割を果たす。本稿では，主に静電 相互作用と疎水性相互作用を利用した分子レベルでのポ ルフィリン分子の配列, 配向制御, 光化学的な性質の制 御を題材として，無機表面と有機分子間の相互作用につ いて考察する。

\section{2 粘土鉱物とポルフィリン色素}

粘土鉱物 ${ }^{3,4)}$ は，（1）原子レベルで平滑な平面を提供 する，（2）密度や発生位置が可変な電荷を有する，（3） 容量が可変な層間微小環境を有する, (4) 化学合成物で は完全に無色である，等の特徵を有する。多くの粘土鉱 物はその骨格中に負電荷を持っている事から，正電荷を 有する有機分子と容易に静電的に複合化する。光機能材 料の視点からは，特に化学合成粘土鉱物においては，そ の分散水溶液や固体膜が透明化できる点も大きな鬼力で ある ${ }^{5)}$ 。Fig. 1 に粘土鉱物の基本骨格を示した。この基 本骨格が二次元に連なり, 広大, かつ, 極めて平滑なシー ト状粒子（Fig. 1（b)）を形成する。サポナイトと呼ば れる粘土鉱物では，表面四面体層の $\mathrm{Si}^{4+}$ が $\mathrm{Al}^{3+}$ に同型 置換することにより負電荷を発生させている。その典型 的な組成式は $\left[\left(\mathrm{Si}_{7.20} \mathrm{Al}_{0.80}\right)\left(\mathrm{Mg}_{6.00}\right) \mathrm{O}_{20}(\mathrm{OH})_{4}\right]^{-0.80} 0.80 \mathrm{Na}^{+}$
で表され，理論表面積は $7.5 \times 10^{5} \mathrm{~m}^{2} \mathrm{~kg}^{-1}$, 理論力チオ ン交換容量 (CEC) は $0.997 \mathrm{mmol} \mathrm{g}^{-1}$ である。粘土鉱 物は固体状態ではナノシート粒子が積層している場合が 多いが，条件によっては，各シート間が膨潤することに より, シート間距離が可逆に変化する。また，水中では 条件により完全に剥離し，1枚シートの状態で分散す る。また, シート上の負電荷の分布は統計的にはへキサ ゴナルを近似できると考えられる。

一方，ポルフィリン色素（Fig.1（d），（e））は，大き な $\pi$ 共役系を持ち, 興味深い光化学特性, ならびに, 酸 化還元特性を有する代表的な機能性色素である ${ }^{6)}$ 。天然 系においては，中心元素として $\mathrm{Mg}, \mathrm{Co}, \mathrm{Fe}$ などを有 する類縁体が，クロロフィル，補酵素などとして重要な 機能を提供している。特に, 光合成においては, その類 縁体が, 光捕集系, 光反応中心の両方で重要な役割を担っ ている。本稿では, 主にカチオン性の tetrakis (1-methyl-pyridinium-4-yl) porphyrin $\left(\mathrm{H}_{2} \mathrm{TMPyP}\right)$ や tetrakis $(N$, $N, N$-trimethyl-anilinium-4-yl) porphyrin ( $\left.\mathrm{H}_{2} \mathrm{TMAP}\right)$ を取り扱う。

\section{3 静電相互作用を利用したポルフィリン分子間距離制御}

一般的な粘土鉱物は負電荷を有するため, 正電荷を有 するゲスト種と容易に複合化する。静電相互作用の他, ファンデルワールスカ, 疎水性相互作用などのバランス により, 吸着力や吸着状態が決定される。しかし, 一般 的には，有機色素分子は無機物表面で著しく会合しやす く, 思い通りに光化学反応系を設計, 作成することは極 めて困難である。特に $\mathrm{H}$ 型会合体や不規則な会合体を 形成した場合には, その電子的励起状態の励起寿命は著 しく短くなり, 分子間反応を行うことが困難となる。我々

a)

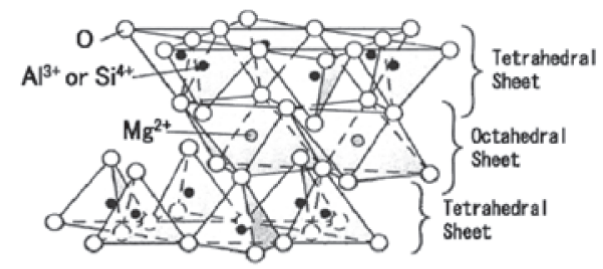

d)

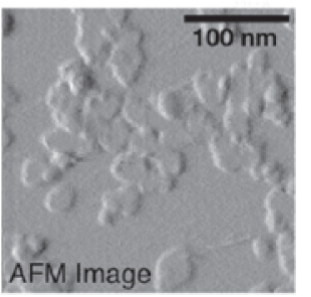

b)

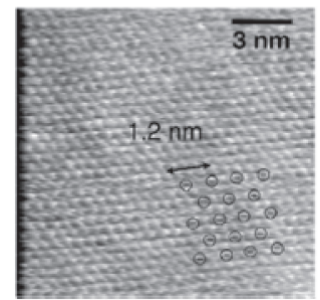

c)

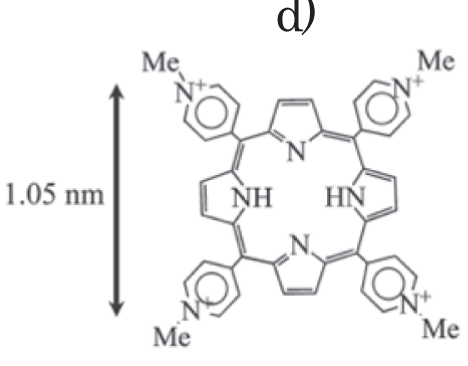

e)

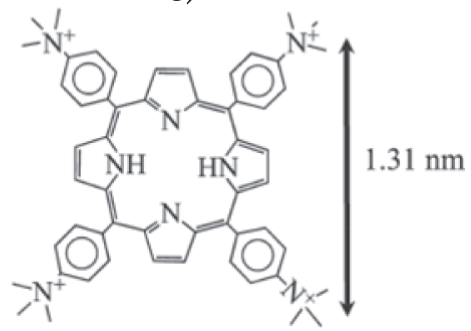

Fig. 1 粘土鉱物（化学合成サポナイト）の単位構造（a）と, 粘土粒子（b），および，その表面拡大 AFM 像（c）。カチオン性 ポルフィリンの構造式, $\mathrm{H}_{2} \mathrm{TMPyP}^{4+}$ (d) と $\mathrm{H}_{2} \mathrm{TMAP}^{4+}$ (e)。 


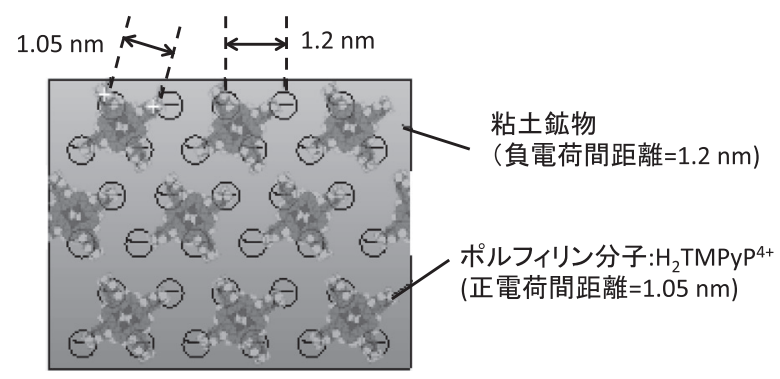

Fig. 2 サイズマッチング則（ゲスト色素分子内正電荷間距 離と, 粘土鉱物上負電荷間距離の関係）による, 粘 土鉱物上におけるポルフィリン分子の高密度無会合 吸着構造のイメージ図。

は，静電相互作用を積極的に利用することにより，粘土 鉱物上におけるポルフィリン色素の高密度無会合構造が 作成可能であることを見出している。このことにより， 粘土一色素複合体における多様な光化学反応が可能とな る。様々な構造を有するポルフィリンを用いた検討の結 果, 吸着構造を決定する重要な因子は, 粘土鉱物上での アニオン電荷間距離とポルフィリン分子内でのカチオン 間距離の一致であることが明らかとなり， Size-Matching Rule（サイズマッチング則）として提唱した（Fig. 2) $\left.)^{1,2}, 7,8\right)$ 。典型的な粘土鉱物上でのポルフィリン平均 分子間距離は $2.4 \mathrm{~nm}$ となり, 基底状態では相互作用が ないが, 電子的励起状態では相互作用が可能な絶妙な分 子間距離を与える。

Fig. 2 の例では，粘土鉱物上とポルフィリン分子内の 電荷間距離に, $0.15 \mathrm{~nm}$ の差（=1.2-1.05 nm）がある。 様々なポルフィリン分子を用いて検討したところ，おお よそ $0.2 \mathrm{~nm}$ 程度の差までは，サイズマッチング則が適 用できることがわかった。すなわち，このことを利用す ると, 異なる電荷密度を有する粘土鉱物を用いることで
ポルフィリン分子間距離を精密に制御可能であることが 予想される。粘土鉱物上の電荷間距離（電荷密度）は, 表面四面体層 $\mathrm{Si}$ の $\mathrm{Al}$ による置換率で決定される。実際 に $\mathrm{Al}$ による置換率を変化させた粘土鉱物を水熱合成し，ポ ルフィリン化合物との複合化についての検討を行った ${ }^{9)}$ 。具 体的には, 組成式 $\left[\left(\mathrm{Si}_{8-\mathrm{x}} \mathrm{Al}_{\mathrm{x}}\right)\left(\mathrm{Mg}_{6-\mathrm{y}} \mathrm{Al}_{\mathrm{y}}\right) \mathrm{O}_{20}(\mathrm{OH})_{4}\right]^{-(\mathrm{x}-\mathrm{y})}$ において $\mathrm{x}=0.33 \sim 1.61$ ののの合成を行った。この $\mathrm{Al}$ 置換率は, 粘土鉱物上の負電荷分布がへキサゴナル であると仮定すると，電荷間距離が，1.92〜0.83 nm で あることに対応している。このような粘土鉱物と, それ ぞれ，分子内電荷間距離が $1.05 \mathrm{~nm}, 1.31 \mathrm{~nm}$ である $\mathrm{H}_{2} \mathrm{TMPyP}^{4+}$ ，および， $\mathrm{H}_{2} \mathrm{TMAP}^{4+}$ (Fig. 1d，e）との複 合化挙動を検討したところ，いずれの組み合わせにおい ても，ポルフィリンは会合すること無く粘土鉱物上に吸 着したが，その飽和吸着量は異なった。すなわち, 飽和 吸着時におけるポルフィリンの平均分子間距離は，粘土 鉱物上の電荷間距離に応じて変化することが明らかと なった。Fig. 3（a）に, 粘土鉱物上の電荷間距離と, 飽 和吸着時におけるポルフィリンの平均分子間距離の関係 を示した。いずれのポルフィリンにおいても，ポルフィ リン分子内の電荷間距離と粘土鉱物表面上の電荷間距離 がほぼ一致した時に，最も平均分子間距離が小さく，す なわち, 高密度な吸着が起きていることがわかる。この ような手法によるポルフィリン分子間距離制御の概念図 をFig. 3（b）に示した。

一方，ポルフィリンとして分子内に正電荷を 8 個持つ ものを用いると分子間距離は長くなり，ポルフィリンと して正電荷を 2 個, 負電荷を 2 個持つものを用いると分

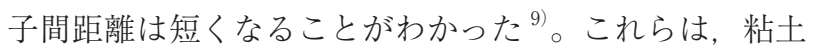
鉱物 -ポルフィリン間の静電相互作用に加えて，ゲスト であるポルフィリン分子間の静電相互作用が加わった結

a)

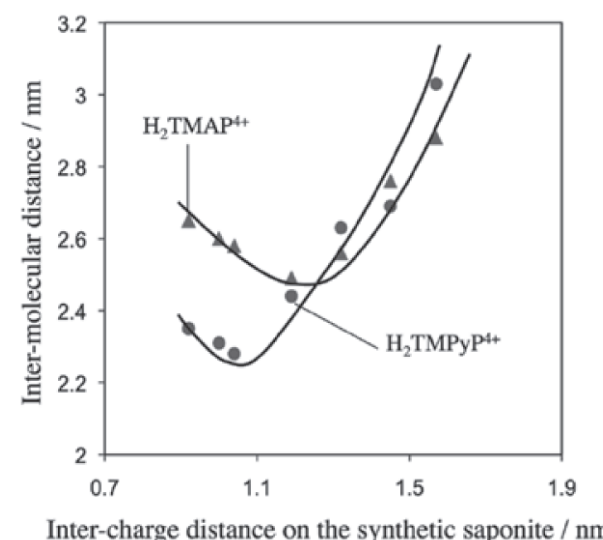

b)
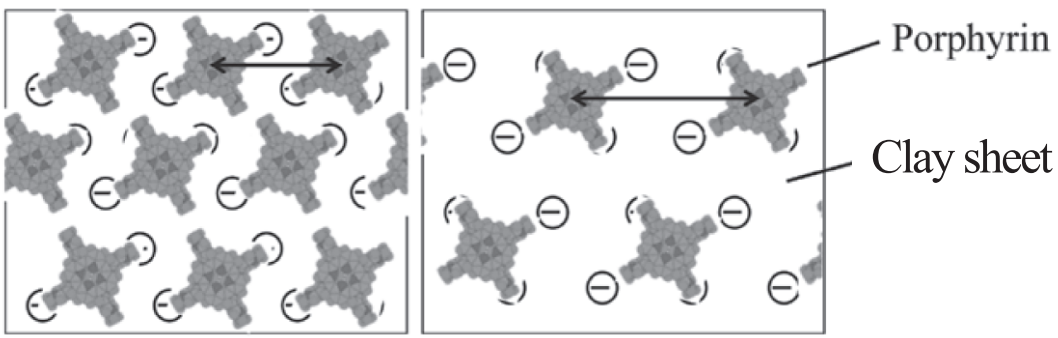

Fig. 3 粘土鉱物上の電荷間距離と飽和吸着時におけるポルフィリンの平均分子間距離の関係（a）と，ポルフィリン分子間距離 制御のイメージ図 (b)。 
果であると考えられる。以上のことより，ホスト材料と ゲスト分子間の静電相互作用，ゲストーゲスト感の静電 相互作用を分子レベルで考えることにより，無機表面に おける有機分子のナノレベルでの集合構造制御が可能で あることがわかった。このことを利用することにより， 高効率なエネルギー移動系の確立に成功し, 人工光捕集 系構築への足がかりを得ている ${ }^{11-13) 。 ~}$

\section{4 疎水性相互作用を利用したポルフィリン分子配向制御}

前節では，主に静電相互作用に基づく無機表面上での ゲスト分子間距離の制御について述べた。しかし，当然 のことながら，物質間での相互作用は複雑であり様々な 相互作用が同時に働いている。本節では，分子内に 2 個 のピリジニウム基, 2 個のフェニル基を有するポルフィ リン $\left(\right.$ cis-DPyP ${ }^{2+}$ (Fig. 4 (a) 右) ) と粘土鉱物からな る複合体の挙動について述べる。この分子においては, 分子の一部のみが粘土鉱物と静電相互作用しうるが, 残 りの疎水部は，吸着に対しどのような効果を及ぼすだろ うか? はじめに，水中に単層剥離分散した粘土鉱物に cis-DPyP ${ }^{2+}$ を吸着させたところ，意外なことに，cis-DPyP $\mathrm{P}^{2+}$ は $\mathrm{H}_{2} \mathrm{TMPyP}^{4+}$ と同様に, 粘土表面に対して水平に吸着 した（Fig. 4（b）左）。cis-DPyP ${ }^{2+}$ が，どのような相互 作用に基づいて粘土鉱物と複合化しているのかを，溶媒 効果, 温度効果の観点から解明を試みた。

ポルフィリン分子が粘土鉱物上において水平配向を 取っているか否かは，その吸収スペクトルの極大吸収波 長，および，導波路上における吸収スペクトルの二色性 ${ }^{14)}$
から決定することができる。溶媒効果は，水中における 各有機溶媒の比率を変化させ検討を行った ${ }^{15-17)}$ 。様々 な有機溶媒の効果を検討したところ，特定の有機溶媒を 粘土-cis- $\mathrm{DPyP}^{2+}$ 複合体に添加することにより，ポル フィリンの吸着配向は, 水平配向から非水平配向に変化 することがわかった。Fig. 5 に各有機溶媒の配向変化の 誘起のしやすさを示した。Fig. 5 の縦軸は，配向変化に 必要な有機溶媒の容量％であり，值が小さいほど少量の 有機溶媒でポルフィリンの非水平配向への配向変化を誘 起することを示す。誘電率, 双極子モーメント, 拡散パ ラメータ, 極性パラメータ, 水素結合パラメータなどの 各種溶媒パラメータと, ポルフィリン配向変化への効果 との間の相関について検討したところ, 溶媒の水素結合 パラメータが極めて高い相関性を示すことが明らかと なった。水素結合パラメー夕は疎水性相互作用と深い関 係があるため，この実験結果は，粘土表面とポルフィリ ン疎水部の疎水性相互作用が，cis-DPyP ${ }^{2+}$ が水平配向を とる際の主要な相互作用であることを強く示唆してい る。

上記の推論を検証するため, 粘土 - cis- $\mathrm{DPyP}^{2+}$ 複合体 における温度効果について検討を行った。Fig. 6 に，ジ メチルホルムアミド／水 $(6 / 4(\mathrm{v} / \mathrm{v}))$ 溶液中での, 粘 土-cis-DPyP $\mathrm{P}^{2+}$ 複合体の吸収スペクトルにおける温度効 果を示した。短波長側の吸収は非水平配向成分によるも のであり，長波長側の吸収は水平配向成分によるもので ある（Fig.6（a））。温度を上げるに従って, 水平配向成 分が増えていることがわかる。この吸収スペクトルより, a)

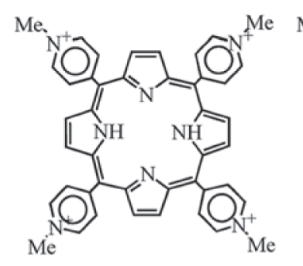

$\mathrm{TMPyP}^{4+}$

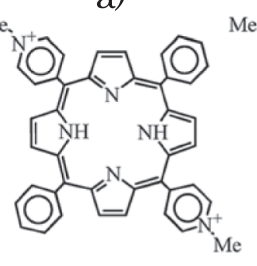

trans-DPyP $\mathrm{P}^{2+}$

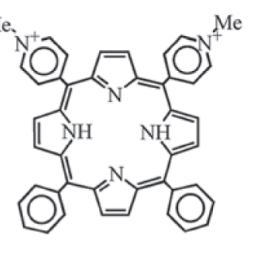

cis-DPyP ${ }^{2+}$

Fig. 4 異なる配置でカチオン性置換基を有するポルフィリン誘導体（a）と, ポルフィリン分子の水平配向と非水平配向のイメー ジ図 (b)。
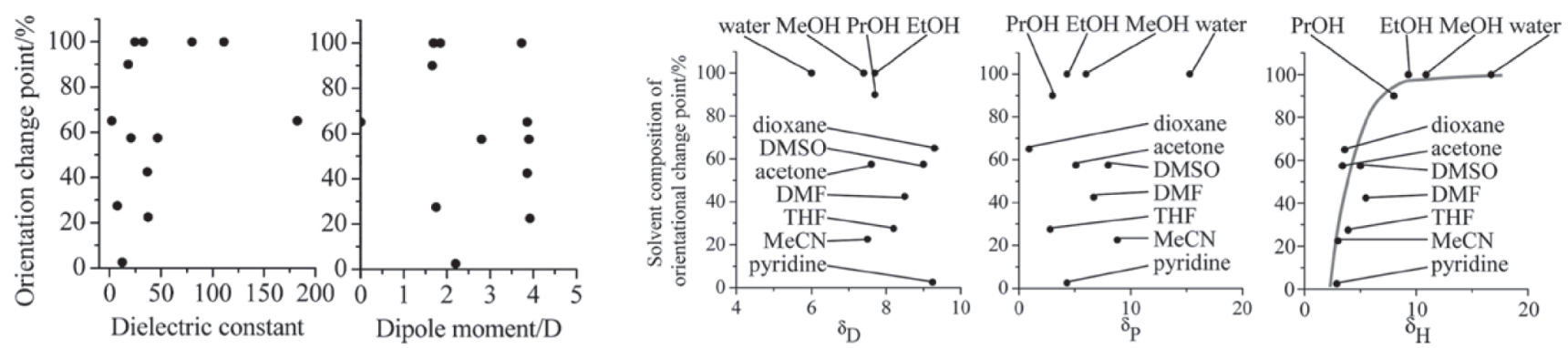

Fig. 5 各種溶媒パラメータとポルフィリン配向変化への効果との間の相関（縦軸は, 配向変化に必要な有機溶媒の容量％）。 
a)

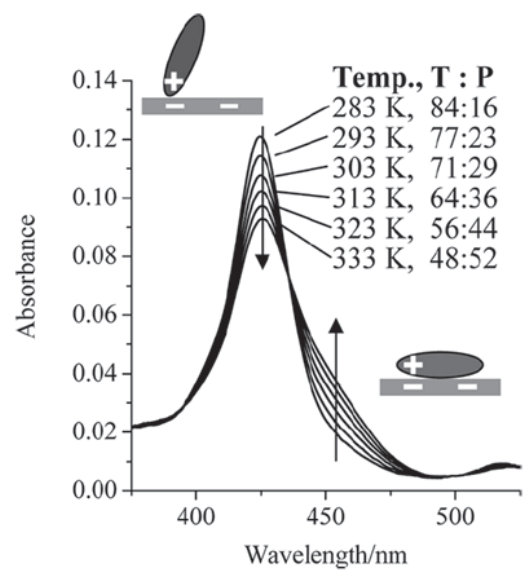

b)

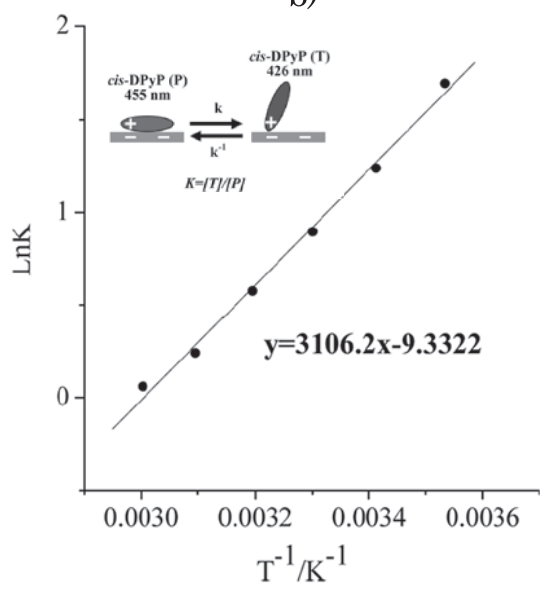

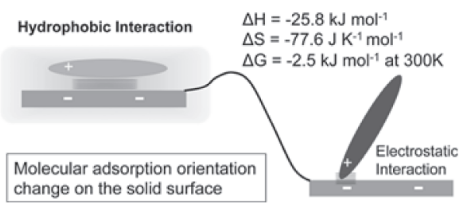

change on the solid surface

Fig. 6 ジメチルホルムアミド / 水 $(6 / 4(\mathrm{v} / \mathrm{v}))$ 溶液中での, 粘土-cis-DPyP ${ }^{2+}$ 複合体の吸収スペクトルに抄ける温度効果（a）と， その van't Hoff plot（b)。

各温度における平衡定数を求め, van’t Hoff plotを作成 した（Fig. 6 (b))。 van't Hoff plotの解析より, 配向変 化における熱力学パラメータは, $\Delta \mathrm{H}=-25.8 \mathrm{~kJ} \mathrm{~mol}^{-1}$, $\Delta \mathrm{S}=-77.6 \mathrm{~J} \mathrm{~K}^{-1} \mathrm{~mol}^{-1}, \Delta \mathrm{G}=-2.5 \mathrm{~kJ} \mathrm{~mol}^{-1}$ (at $300 \mathrm{~K})$ と求まった。このことより, エンタルピー的に は非水平配向が有利であり，エントロピー的には水平配 向が有利であることがわかった。ここで，疎水性相互作 用について考えてみると, その起源はエントロピー項で あるとする説が有力である。エントロピー的に不利な水 素結合ネットワークにあずかる水分子の数を減らすこと が，疎水性相互作用の主な起源であるとする考え方であ る。すなわち, 非水平配向の時には, ポルフィリン，及 び，粘土鉱物周辺に形成される水分子のネットワーク形 成の容量が大きいが, 水平配向状態となることで水分子 のネットワーク形成の容量が小さくなる, 従って, エン トロピー的に, 水平配向が有利になると考えることがで きる。以上のことを総合して考えると, 周囲の環境を変 えることによる疎水性相互作用の制御により，ポルフィ リン分子の配向状態を制御可能であると考えることがで きる。

\section{5 粘土鉱物ーポルフィリン色素複合体の応用研究}

ここまで，粘土鉱物－ポルフィリン色素複合体の分子 レベルでの複合体構造変化の基礎的挙動について述べて きた。このような, 構造制御技術を用いれば多くの応用 的な研究を論理的に進めることができる。特に, これら の分子集合構造制御技術は, 時間と距離に鋭敏に左右さ れる光化学反応を行う際に大变効果的，かつ，有用であ る。

ポルフィリン分子間距離制御の技術を用いれば, 励起 寿命を保ったままポルフィリン色素の高密度構造を作成

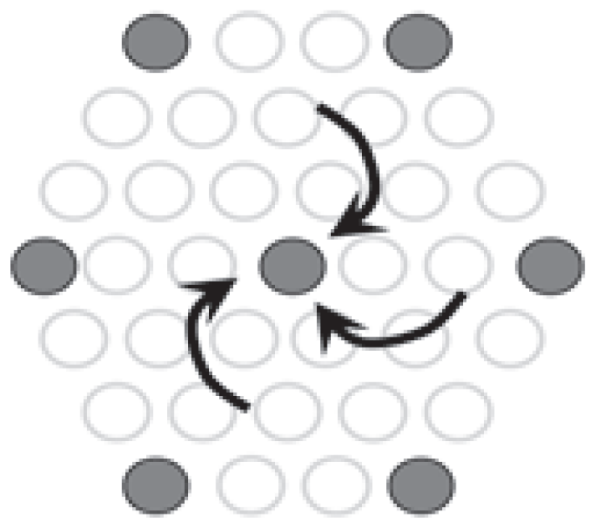

Fig. 7 粘土鉱物上における光捕集型エネルギー移動の模式 図（○：エネルギー供与体，○：エネルギー受容体）。

することができ，このような構造は人工光捕集系への展 開が可能である $(F i g .7)^{11-13)}$ 。実際に, エネルギー供与 体とエネルギー受容体を粘土鉱物上に混在させることに より, 効率の良いエネルギー移動系を構築することが出 来た。分子間距離の制御により，i）会合体形成（基底 状態での色素間相互作用）抑制によるエネルギー供与体 分子の短寿命化の抑制, ii ) 色素分子の固定化によるエ ネルギー移動過程以外の蛍光消光（電子移動反応等によ る消光), 及び, 自己消光の抑制, iii）エネルギー供与 体とエネルギー受容体が相分離せず有効な隣接が起きる こと，などの効果を実現することができる。

ポルフィリン分子配向制御の技術を用いれば, 光化学 反応の効率制御や, 環境応答性色素材料などに応用可能 である。カチオン性ポルフィリンは, 前述のように, 水 平配向状態では通常の状態に比べて極大吸収波長が大き く長波長シフトしている。これは, 粘土鉱物の高い平面 性を反映して，ポルフィリン分子全体が共平面化するこ 
とによる ${ }^{18)}$ 。一方，非水平配向になると分子内の共平 面化が緩和され，長波長シフトが解消される。従って， 周囲の環境に応じて, ポルフィリンの吸着配向が変化し, その結果, ポルフィリンの色調が変化するという興味深 い現象が起きる。実際の材料化を視野に入れ，粘土鉱物 ーポルフィリン複合膜の作成について検討した。その結 果，透明な複合膜を作成できることが明らかとなり，実 際に環境によって, 緑色（空気，ヘキサン，シクロヘキ サン), 褐色 (水, アセトン), ピンク色（ジオキサン, ジメチルホルムアミド）と可逆に色調変化が起きること がわかった ${ }^{16)}$ 。すなわち，ソルバトクロミズム材料と して機能することが明らかとなったが，そのメカニズム がポルフィリンの配向変化に基づくという点が大変工 ニークである。この配向変化のしやすさはポルフィリン の構造に強く依存する。分子内に正電荷を 2 個, 負電荷 を 2 個有する両性ポルフィリンでは，水中では水平配向 であるが，微量の有機溶媒の添加により極めて容易に配 向変化を起こす。両性ポルフィリンでは, 分子内に負電 荷を有するため, 粘土鉱物上の負電荷と静電的な反発を するためである。

また，色素が粘土鉱物表面に固定化されることは，擬似 的な結晶状態と考えることができる。すなわち，溶液中に 溶解している場合とは異なり, 色素の分子運動の固定化, 色素の構造変化などが起こり, 様々な光化学特性が変化す る。例えば，溶液中で無蛍光性の色素が粘土鉱物上では 発光性になるなどの興味深い現象が観察され る ${ }^{19,20)}$ 。単分子の物性制御のみならず，化学反応そのもの を制御できる可能性も見出されており，夢は尽きない ${ }^{21)}$ 。

\section{6 まとめ}

本稿では，ホスト材料として粘土鉱物，ゲスト分子と してポルフィリン化合物を取り上げ，その複合体形成挙 動について，主に，静電相互作用と疎水性相互作用の視 点から議論した。もちろん, 実際の相互作用は極めて複 雑であり，実際の系は多くの相互作用のバランスによっ て成り立っているが, 多点の静電相互作用や, 平面型の ホスト・ゲストを用いることで，ひとつの相互作用を強 力に働かせ，論理的に分子レベルでの複合体構造制御を 行うことができる可能性がある。さらに，ゲストーゲス 卜間の相互作用を加えることで，より精密なゲス卜分子 間距離の制御が可能なこともわかってきた。界面におけ る，無機物と有機物の相互作用は普遍的に重要な研究課 題と思われるが，粘土鉱物－機能性色素複合体は，その 好適な研究モデルとなりうる。本稿で示した研究例はそ の可能性を強く感じさせるものであると考えている。こ
のようなモデルのもとに，さらに基礎的な知見を重ねる ことが，長い目でみれば，応用，実用に対しても大きな 意義を持つものと信じている。本稿は，ざっくりとした 記述となってしまっており，細かい点でのご批判も多い かと思われるが, 油化学の進展に少しでも刺激となれば 幸いである。

\section{文 献}

1) S. Takagi, T. Shimada, Y. Ishida, T. Fujimura, D. Masui, H. Tachibana, M. Eguchi, H. Inoue, Langmuir, 29, 2108 (2013)

2) S. Takagi, M. Eguchi, D. A. Tryk, H. Inoue, J. Photochem. Photobiol. C: Photochem. Rev., 7, 104 (2006).

3) M. Ogawa, Y. Ide, T. Okada, Chem.-Asian J., 7, 1980 (2010).

4) K. Takagi, T. Shichi, J. Photochem. Photobiol., C, 1, 113 (2000).

5) T. Fujimura, T. Shimada, S. Hamatani, S. Onodera, R. Sasai, H. Inoue, S. Takagi, Langmuir, 29, 5060 (2013).

6) S. Takagi, H. Inoue, Molecular and Supramolecular Photochemistry, 4, 215, Mercel Dekker (1999).

7) S. Takagi, T. Shimada, M. Eguchi, T. Yui, H. Yoshida, D. A. Tryk, H. Inoue, Langmuir, 18, 2265 (2002).

8) M. Eguchi, S. Takagi, H. Tachibana, H. Inoue, J. Phys. Chem. Solids, 65, 403 (2004).

9) T. Egawa, H. Watanabe, T. Fujimura, Y. Ishida, M. Yamato, D. Masui, T. Shimada, H. Tachibana, H. Yoshida, H. Inoue, S. Takagi, Langmuir, 27, 10722 (2011).

10) S. Takagi, S. Konno, Y. Aratake, D. Masui, T. Shimada, H. Tachibana, H. Inoue, Microporous \& Mesoporous Materials, 141, 38 (2011).

11) Y. Ishida, T. Shimada, D. Masui, H. Tachibana, H. Inoue, S. Takagi, J. Am. Chem. Soc., 133, 14280 (2011).

12) Y. Ishida, R. Kulasekharan, T. Shimada, S. Takagi, V. Ramamurthy, Langmuir, 29, 1748 (2013).

13) Y. Ishida, T. Shimada, S. Takagi, J. Phys. Chem. C, 117, 9154 (2013).

14) M. Eguchi, H. Tachibana, S. Takagi, D. A. Tryk, H. Inoue, Bull. Chem. Soc. Jpn., 80, 1350 (2007).

15) M. Eguchi, S. Takagi, H. Inoue, Chem. Lett., 35, 14 (2006).

16) S. Takagi, T. Shimada, D. Masui, H. Tachibana, Y. Ishida, D. A. Tryk, H. Inoue, Langmuir, 26, 4639 (2010).

17) M. Eguchi, T. Shimada, D. A. Tryk, H. Inoue, S. Takagi, J. Phys. Chem. C, 117, 9245 (2013).

18) Y. Ishida, D. Masui, T. Shimada, H. Tachibana, H. Inoue, S. Takagi, J. Phys. Chem. C, 116, 7879 (2012).

19) T. Tsukamoto, T. Shimada, S. Takagi, J. Phys. Chem. C, 117, 2774 (2013).

20) T. Tsukamoto, T. Shimada, S.Takagi, J. Phys. Chem. A, 117, 7823 (2013).

21) T. Umemoto, Y. Ohtani, T. Tsukamoto, T. Shimada, S. Takagi, Chem. Commun., 50, 314 (2014). 